Egypt. Acad. J. biolog. Sci., 2 (2): 119-123 (2009)

Email: egyptianacademic@yahoo.com

Received: 15/11/2009
A. Entomology

ISSN: 1687-8809

www.eajbs.eg.net

\title{
Effect of Saccharicoccus sacchari (Cockerell) infestation levels on sugarcane physical and chemical properties
}

\author{
Gamal El-Dein, H. Mohamed; Sanaa, A. M. Ibrahim and Fatma, A. Moharum \\ Plant Protection Research Institute, Dokki, Giza 12618, Egypt.
}

\begin{abstract}
The present investigation was carried out in Sohage Governorate, Egypt on sugarcane infested with Saccharicoccus sacchari (Cockerell) (Hemiptera: Pseudococcidae) during growing year 2007/2008. Obtained results indicated that only sever infestation significantly affected sugarcane physical and chemical properties. There were reduction of stalk's weight $(5.03,34.33 \%)$, stalk's height $(2.16,6.93 \%)$, stalk internodes' number per stalk $(8.8,29.07)$ and juice weight $(2.26,31.62 \%)$ in low and heavy Infestation, respectively compared with infestation free. Internodes height increased by 8.59 and $35.45 \%$ due to low and sever levels of infestation, respectively. There were losses of brix $(4.95,13.47 \%)$, sucrose $(6.29,27.87 \%)$, purity $(1.41$, $16.87 \%)$, pol $(5.29,32.6 \%)$ and sugar recovery $(5.29,37.08 \%)$ and increase of reducing sugar $(3.53,7.68 \%)$ and fiber $(1.28,3.85 \%)$ due low and heavy levels of infestation, respectively.
\end{abstract}

Key Words: Saccharicoccus sacchari, level of infestation, physical and chemical properties of sugarcane

\section{INRODUCTION}

Sugarcane Saccharum officinarum L. is considered the main materials for sugar processing (Darwish, 1979). The sugarcane plantation area in Egypt reached about 350,000 feddans, producing 16 million tons of sugarcane in 2007 (Anonymous, 2008). Sugarcane in Egypt is subject o seven major pests and 24 other minor pests. The major pests are the pyrallid Chilo agamemnon, the noctuid Sesamia cretica, the coccid Pulvinaria tenuivalvata, three scrarabids and the pseudococcid Saccharicoccus sacchari (Cockerell) (Hemiptera : Pseudococcidae)) (Abd-Rabou and Parker, 2008).

The damage caused by the mealy bug $S$. sacchari occurs partly by sucking the plant sap and so leading to a group of thinner and stunted canes. The most serious loss, however, occurs from the industrial point of view, as the honey dew excreted by the mealy bug on the can surface, together with the exudation of gums from parts wounded by the piercing mouth parts of the insects seriously interfere with the row sugar juice leading to a depression in the amount of sugar crystallized during the manufacturing process (Willcocks, 1925).

Atiqui and Murad (1992) assessed sucrose and sugar content (brix, pol and purity) losses as $10.64,16.44,6.14$ and $12.92 \%$, respectively as a result of $S$. sacchari infestation. Yield damage caused to sugarcane by Pulvinaria iceryi (Signoret) (Hemiptera: Coccidae) and Aulacaspis tegalensis (Zhnt.) (Hemiptera: Diapspididae) are cane weight and sucrose content losses (Anonymous, 1987). Saleh (2005) reported significant relationship between five levels infestation of effect Pulvinaria tenuivalvata (Newstead) (Hemiptera: Coccidae) on the yield and quality some characters of sugarcane. Goel et al., (1983) indicated that heavily infestation by Melanaspis glomerata (Green) (Hemiptera: Diapspididae) on cane cased cane weight, 
juice brix, sucrose content of the juice and purity losses of $51.61,27.69,39.0$ and $13.39 \%$, respectively.

This work aimed to evaluate damage cased by low and sever levels of infestation of $S$. sacchari on sugarcane quantitative and qualitative characters and juice production.

\section{MATERIAL AND METHODS}

The present investigation was carried out at Gerga, Sohage Governorate, Egypt during a single growing year 2007/2008 (i.e. from Apr. 2007 to Apr. 2008). The design of experiments was as follows:

An area of about half feddan (i.e. $2000 \mathrm{~m}^{2}$ ) was divided into three parts according to level of infestation as low, sever and free of infestation. Identification of S. sacchari was carried out by first and third author, using the insect cutes collection list.

Asample of 25 internodes were chosen at random from each division under investigation and replicated 3 times. The samples were examination, using a magnifying glass at monthly basis. Alive stages found on each sample were recorded as: pre-adult and females.

Assessment of certain physical properties of sugarcane variety C.9/54, was carried out at harvesting time (i.e. 12 Apr. 2008). A sample of 10 stalks (replicate 3 times) representing each division was taken as random to determine the following parameters: stalk weight (g.), stalk height $(\mathrm{m})$, high of internodes $(\mathrm{cm})$, internodes number of stalk and juice weight $(\mathrm{g})$.

Chemical analysis of sugarcane juice produced (after one hour from harvesting) from these stalks was conducted. One and half liter juice of them was taken in glass cylinder for calculating the characters according to the formula described by methods of Sugar and Integrated Industries Company (S.I.I.C.) (Mathur, 1981) to determine the following parameters:

*Brix percent (the percent of total soluble solids in $100 \mathrm{ml}$ of juice) was measured by brix hydrometer standardized at $20^{\circ} \mathrm{C}$ in the laboratory.

*Sucrose percent which was determined by using Saccarometer according to A.O.A.C. (Anonymous, 1995).

*Purity percent was calculated according to the following equation,

Purity $\%=($ Sucrose $\% /$ brix $\%) \times 100$.

$*$ Pol. $=($ Sucrose \% $) \times$ Pol factor.

* Fiber \%, and Reducing sugar percent were determined according to the method described in (Mathur, 1981).

*Sugar recovery percent was calculated according to the following equation, Sugar recovery $\%=$ Richness $\% \times$ Purity $\%$.

- Richness $=($ Sucrose in $100 \mathrm{mg} \times$ factor $) / 100$.

-Factor $=100$ - (fiber $\%+$ physical impurities $\%+$ percent water free from sugar).

Statistical analysis as analysis of variance was conducted to clarify the significance between obtained levels of damage.

\section{RESULTS AND DISCUSSION}

Data in Table (1) show monthly mean counts of $S$. sacchari recorded on each monthly count as pre-adults and females. Counts mean were $73.5 \& 19.1$ for low 
infestation and $757.5 \& 256.6$ for sever infestation. The data indicated low infestation harbored about $10 \%$ of the sever one.

Table (1): Monthly mean number of S. sacchari recorded on 25 internodes of infested sugarcane.

\begin{tabular}{|c|c|c|c|c|c|c|}
\hline \multirow{2}{*}{ Date } & \multicolumn{3}{|c|}{ Low infestation } & \multicolumn{3}{c|}{ Sever infestation } \\
\cline { 2 - 7 } & Pre-adults & $\begin{array}{c}\text { Adult } \\
\text { females }\end{array}$ & Total & Pre-adults & $\begin{array}{c}\text { Adult } \\
\text { females }\end{array}$ & Total \\
\hline Apr. 2007 & 49.3 & 7.6 & 57 & 483.6 & 91 & 534.8 \\
\hline May 2007 & 112.4 & 19.3 & 155.7 & 1298.1 & 277.1 & 1575.3 \\
\hline Jun. 2007 & 87.2 & 6.8 & 94 & 854.9 & 81.1 & 936 \\
\hline Jul. 2007 & 47.2 & 8.1 & 55.3 & 462.9 & 96.5 & 559.4 \\
\hline Aug. 2007 & 83.4 & 37.1 & 140.6 & 916.1 & 561 & 1477.1 \\
\hline Sept. 2007 & 209.4 & 68.7 & 292.1 & 2092.4 & 936.9 & 3029.3 \\
\hline Oct. 2007 & 132.9 & 51.5 & 188.4 & 1303.1 & 660.8 & 1963.9 \\
\hline Nov. 2007 & 67.6 & 14.4 & 92 & 760.6 & 171.9 & 932.5 \\
\hline Dec. 2007 & 47.8 & 5.7 & 53.6 & 468.9 & 68.4 & 537.3 \\
\hline Jan. 2008 & 8.6 & 1.5 & 11.1 & 94.4 & 17.6 & 112 \\
\hline Feb. 2008 & 14.1 & 2.1 & 16.2 & 138.6 & 24.8 & 163.4 \\
\hline Mar. 2008 & 22.1 & 6.7 & 29.8 & 216.4 & 91.9 & 308.3 \\
\hline Total & 882 & 229.5 & 1185.8 & 9090 & 3078.9 & 12129 \\
\hline Mean & 73.5 & 19.1 & 98.8 & 757.5 & 256.6 & 1010.8 \\
\hline
\end{tabular}

Results for cane physical properties are presented in Table (2). Results show that weight of stalk was decreased by $5.03 \%$ in the low infestation and $34.33 \%$ of sever infestation compared with free of infestation. This reduction was on significance between low and free of infestation. For height of stalks there was no significance between different tested levels of infestation. Internodes' height increased by 8.59 and $35.45 \%$ due to low and sever infestation, respectively. This increase was not significance between low and infestation free. The number of internodes/stalk was reduced at sever infestation by $29.07 \%$ while at low infestation it was $8.80 \%$. This reduction was not clearly significance between different levels of infestation. Juice weight showed reduction of 2.26 and $31.62 \%$ for low and sever infestation. This indicated significance differences between sever infestation and others.

Table (2): Effect of levels of infestation with S. sacchari on physical properties of sugarcane at harvesting time (12 Apr. 2008).

\begin{tabular}{|c|c|c|c|c|c|}
\hline Infestation level & $\begin{array}{c}\text { Stalk } \\
\text { weight }(\mathrm{g} .)\end{array}$ & $\begin{array}{c}\text { Height of } \\
\text { stalk (m.) }\end{array}$ & $\begin{array}{c}\text { High of } \\
\text { internodes } \\
(\mathrm{cm} .)\end{array}$ & $\begin{array}{c}\text { No. } \\
\text { internodes/stalk }\end{array}$ & $\begin{array}{c}\text { Juice } \\
\text { weight } \\
(\mathrm{g} .)\end{array}$ \\
\hline $\begin{array}{c}\text { Free of } \\
\text { infestation }\end{array}$ & $935 \mathrm{a}$ & $2.31 \mathrm{a}$ & $20.69 \mathrm{a}$ & $21.6 \mathrm{a}$ & $587 \mathrm{a}$ \\
\hline Low infestation & $888 \mathrm{a}$ & $2.26 \mathrm{a}$ & $22.47 \mathrm{a}$ & $19.70 \mathrm{a}$ & $574 \mathrm{a}$ \\
\hline Sever infestation & $614 \mathrm{~b}$ & $2.15 \mathrm{a}$ & $28.03 \mathrm{~b}$ & $15.32 \mathrm{ab}$ & $402 \mathrm{~b}$ \\
\hline L.S.D & 63.75 & 0.4 & 5.54 & 3.46 & 148.81 \\
\hline
\end{tabular}

Results for extracted cane juice properties are presented in Table (3). Results showed the effect of infestation on percentages of brix which was reduced by 4.95 and $13.47 \%$ of low and sever infestation, respectively with on significance between tested levels of infestation. Similar was sucrose percent which was reduced at by 6.29 and $27.87 \%$ for low and sever infestation with on significance between tested levels. Percent of purity was reduced by $1.41 \%$ at low infestation level. This reduction was not significant from free if infestation. Sever infestation resulted in significant reduction of $16.87 \%$ compared with others. Reducing sugar increased insignificantly as infestation level increased as $3.53 \%$ and $35.45 \%$, respectively. Percent of fiber 
also was not affected by differences between the level of infestation. The pol value was reduced significantly as result of sever infestation compared with other levels. It was 32.62 and $5.29 \%$ for sever and low infestation levels respectively. Sugar recovery was not significantly reduced by low of infestation (i.e. $5.29 \%$ ) while it was reduced significantly by sever infestation (i.e. $37.08 \%$ ).

Table (3): Effect of levels of infestation with S. sacchari on certain chemical properties of sugar can juice at harvesting time (12 Apr.2008).

\begin{tabular}{|c|c|c|c|c|c|c|c|}
\hline Infestation level & Brix & Sucrose \% & Purity \% & Reducing Sugar \% & Fiber \% & Pol & Sugar recovery\% \\
\hline Free of infestation & $18.78 \mathrm{a}$ & $15.75 \mathrm{a}$ & $83.86 \mathrm{a}$ & $5.67 \mathrm{a}$ & $12.48 \mathrm{a}$ & $13.98 \mathrm{a}$ & $13.98 \mathrm{a}$ \\
\hline Low infestation & $17.85 \mathrm{a}$ & $14.76 \mathrm{a}$ & $82.68 \mathrm{a}$ & $5.87 \mathrm{a}$ & $12.64 \mathrm{a}$ & $13.24 \mathrm{a}$ & $13.24 \mathrm{a}$ \\
\hline Sever infestation & $16.25 \mathrm{a}$ & $11.36 \mathrm{a}$ & $69.71 \mathrm{~b}$ & $7.68 \mathrm{a}$ & $12.96 \mathrm{a}$ & $9.42 \mathrm{~b}$ & $7.74 \mathrm{~b}$ \\
\hline L.S.D & 5.65 & 4.8 & 4.98 & 2.77 & 0.59 & 3.2 & 4.06 \\
\hline
\end{tabular}

Generally the obtained results indicated that low level of infestation did not significantly affected sugarcane physical and chemical properties while sever one did.

These results are in agreement with Atiqui and Murad (1992) who assessed the loss of sucrose content of sugarcane infestation by S. sacchari as decreased of sucrose and sugar content of the cane and its purity (with average losses in sugar brix, pol, purity and available sugar content were $10.64,16.44,6.14$ and $12.92 \%$, respectively). Goel et al. (1983) indicated that in heavily infestation by M. glomerata on cane were the cane weight, juice brix, sucrose content of the juice and purity were reduced by 51.61, 27.69, 39.0 and 13.39 \%, respectively. Anonymous (1987) mentioned to yield losses caused to sugarcane by $P$. iceryi and damage level of the 2 components of loss, cane weight and sucrose content. Besheit et al. (2002) studied the effect of $P$. tenuivalvata on the yield and quality of sugarcane. The data indicated that under heavy infestation reduction percent recorded 51.24, 32.96, 46.08, 61.51, 73.24 and 31.24 for average stalk weight, juice extraction percentage, brix, (\% Richness), \% sugar extracted (rendment) and purity. Shalaby (2002) found there was significant reduction in weight of cane to $22.9 \%$ infested cane by $P$. tenuivalvata and reduction in juice extraction and percent sucrose averaged $28.62 \%$ and $4.13 \%$, respectively. Saleh (2005) reported that there were significant differences between infestation levels by $P$. tenuivalvata and stalk weight, stalk height, stalk of internodes number and juice weight. Percent of brix, purity, sucrose, purity, richness and sugar recovery were decreased by increasing the percent of infestation by $P$. tenuivalvata.

Further studies are required to determine the level of infestation which require introduction of control measurements.

\section{REFERENCES}

Abd-Rabou, S. and B. Parker (2008). A review of sugarcane pests in Egypt. Egypt J. Agric. Res., 86 (1): 1- 42.

Anonymous (1987). A report from Mauritius Sugar Institute.

Anonymous (1995). Official methods of analysis. Association of Official Agricultural Chemists (A.O.A.C.), Washington D.C., USA.

Anonymous (2007). Agricultural statistics, winter crops. Ministry of Agriculture, Egypt, Vol. (1) Dec. 2008. 150 pp. 
Atiqui, M.U.A. and H. Murad (1992). Assessment of loss in sucrose content of sugarcane due to sugarcane mealy bug, Saccharicoccus sacchari (Ckll). J. Insect Sci. 5 (2): 196 - 197.

Besheit, S. Y.; A. A. Abaziad; A. M. El-Gomaa; A. S. Abo El-Hamd (2002). The influence of the infestation by the soft scale insect Pulvinaria tenuivalvata (Newstead) Homoptera: Coccidae on sugarcane stalk weight, juice quality and sugar yield in Upper Egypt. Egypt, Assut J. of Agric. Sci. 33(4):17-28

Darwish, Y. Y. I. (1979). Fertilizer requirements of sugarcane in Kom-Ombo. M. Sc. Thesis, Fac. Agic., Alexandria Univ. 119 pp.

Goel, S. C.; T. A. V. S. Raghunath and S. C. Goel (1983). Losses due to scale insect in sugarcane variety CO. A 7602. Insect Ecology and Resource Management, 1983:142-146.

Mathur, R. B. L. (1981). Handbook of cane sugar technology. Second revised and enlarged edition. Oxford and IBH publishing Co. Pvt. Ltd., New Delhi and Calcuta.

Shalaby, M. S. I. (2002). Ecological and biological studies on the sugarcane scale Pulvinaria tenuivalvata (Newstead) infesting sugarcane in Giza Governorate. Ph. D. Thesis, Fac. Agic., Al-Azhar Univ. 209 pp.

Saleh, H. A. (2005). Impact of the red striped soft scale insect, Pulvinaria tenuivalvata (Newstead) infestation on the quantity and quality plant of sugarcane under certain cultural practices $\mathrm{Ph}$. D. Thesis, Fac. Agric. Cairo Univ. Egypt, $143 \mathrm{pp}$.

Willcocks, F. C. (1925). The insect and related pests of Egypt II. Insects and mites feeding on graminous crops and products in the field, granary and mill. Sultanic Agric. Soc., II, Cairo.

\section{ARABIC SUMMARY}

$$
\begin{aligned}
& \text { تأثير مستويات مختلفة من الإصابة بحشرة بق القصب الاقيقى على الصفات الطبيعية و الكيمائية }
\end{aligned}
$$

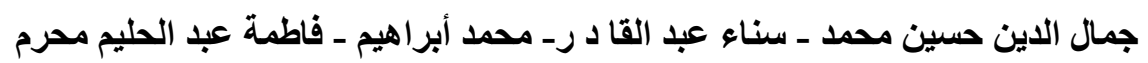

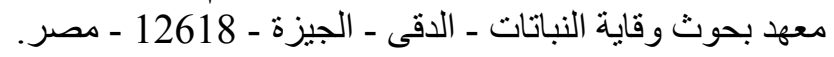

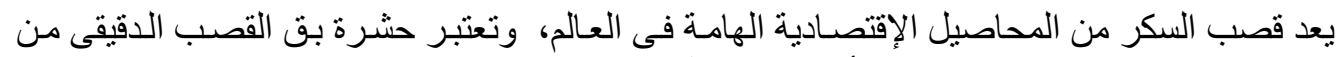

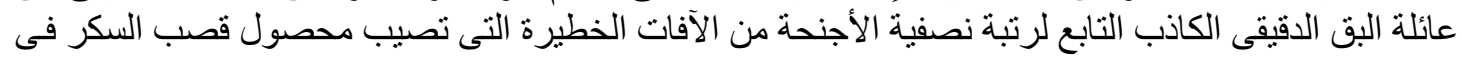

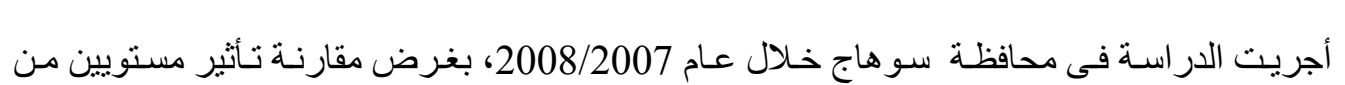

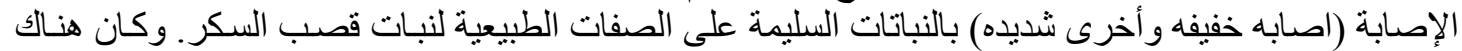

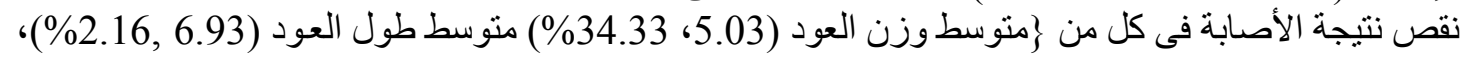

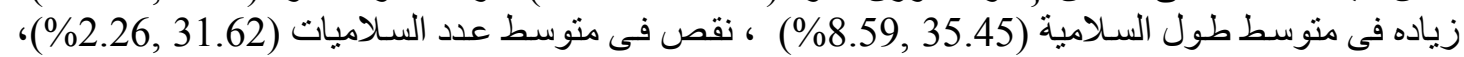

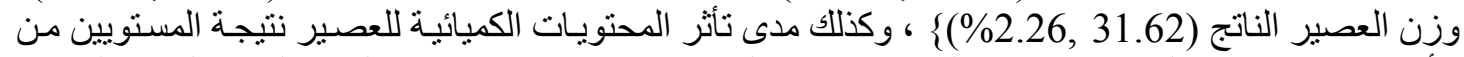

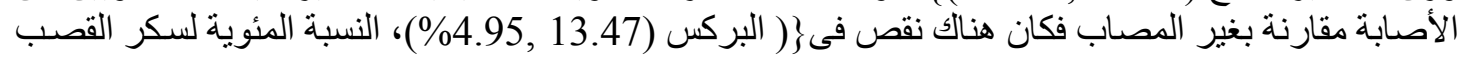

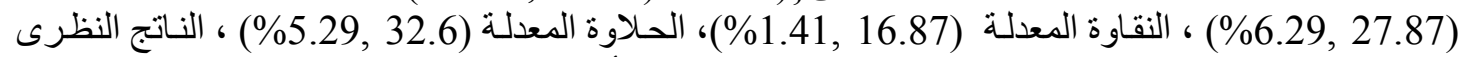

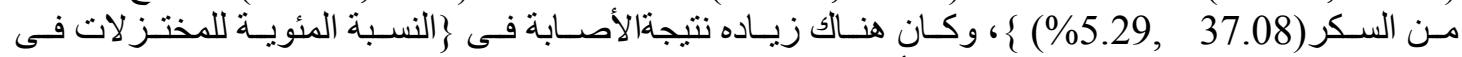

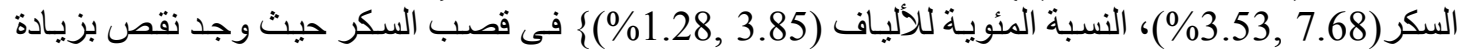

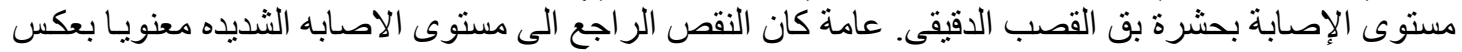

